DOI 10.18551/rjoas.2020-08.10

\title{
THE FUTURE OF AGRARIAN VILLAGE: AGRARIAN SECURITY AND DEAGRARIANIZATION PROBLEM IN INDONESIA
}

\author{
Pujiriyani Dwi Wulan* \\ Sekolah Tinggi Pertanahan Nasional, Yogyakarta, Indonesia \\ Soetarto Endriatmo \\ Faculty of Human Ecology, IPB University, Bogor, Indonesia \\ Santosa Dwi Andreas \\ Faculty of Agriculture, IPB University, Bogor, Indonesia \\ Agusta Ivanovich \\ Faculty of Human Ecology, IPB University, Bogor, Indonesia \\ *E-mail: lucia wulan@yahoo.com
}

\begin{abstract}
Deagrarianization marks changes in rural areas worldwide. Villages are no longer associated with agriculture as the main livelihood. Agriculture began to be neglected, in particular by younger generation as it's assumed to unable to fulfill the desired welfare standards. This study was aimed to analyse the dimensions of agrarian security and agricultural community strategies in developing agrarian security. The study was conducted using the community case study method. Emic perspective was applied in this study by close reading through an ethnographic approach. Field research was conducted in mid 2017 until the beginning of 2019. The study involved 42 informants from the older and younger generations in the community. The results showed that agrarian security supports the community to survive as a solid agrarian community with their agrarian lifestyle. Land availability, land access, land use orientation, and community stability are amongst the dimensions of agrarian security that support the existence of the agricultural community.
\end{abstract}

\section{KEY WORDS}

Agrarian security, agrarian village, agricultural community.

Deagrarianization is a terminology used to describe the process of shifting social structures from agrarian to non-agrarian society (Bryceson 1996; Rigg 2006). The problem of peasants regeneration crisis in deagrarianization arose as agriculture tends to be conducted by older generation or what Rigg et al. (2016) has referred to as the phenomenon of 'Asia's greying peasants'. Several terms appeared to describe that villages were no longer identical to the existence of peasants and agricultural activities, such as: 'farewell to farm' (Bryceson 1996), 'vanishing village' (Gupta 2005), 'the shrinking of agrarianism' (Halamska 2011), and 'demish of peasantry' (Misra 2017).

Agriculture, which is no longer a characteristic of the village and peasants' withdrawal from agricultural sector as shown by the symptoms of deagrarianization, are serious threats not only at micro level for rural communities, but also at macro level for country's food security (Bryceson 2010; Hisano et al, 2018). Japan could be one of the examples where deagrarianization ever made the situation of food security vulnerable. Japanese food imports experienced a massive ramp-up due to the large number of unproductive (unworked) agricultural lands and the tendency of the aging peasants.

The neglected agricultures or the aging of the rural area as an impact of deagrarianization worldwide also occurred in Indonesia. Deagrarianization in rural areas were marked by a downturn in the role of villages as food barns and an increasing peasants' detachment from agricultural sector by switching into non-agricultural sectors. Villages were 
merely regarded as a place to return back home or to spend retirement days, but not as a place to rely upon to obtain a source of income (White et al. 2012; Soetarto dan Agusta 2012; Setiawan 2013).

\section{LITERATURE REVIEW}

Among various studies on deagrarianization, the originality of this study lies in contextualising the study of deagrarianization with agrarian security in the rural areas. Previous deagranianization studies had not given attention to the existence of agrarian landscape and their communities as a whole thing. The undertaken study highlighted the concept of 'livelihood' and put deagrarianization as a consequence of adaptation strategies to cover the shortfall of income in agricultural sector. Communities were placed separately from the agrarian landscapes (McAllister 1999; Connor \& Mtwana 2017; Grivins \& Tisenkopfs 2018).

Literature studies pointed out that the concept of agrarian security has yet to be raised. Food security is known to be a more popular concept (Van Dijk \& Meijerink 2014; Tendall et al 2015). Agrarian security is a new concept in deagrarianization studies. The agrarian security highlighted in this paper means the ability of agricultural community to defend its agrarian landscape against the threat of deagrarianization, causing dwindle to characteristic of an agrarian village. As mentioned by West and Haug (2017), agricultural communities are basically very adaptive to changes as they have a capacity of endurance.

The concept that is quite close to agrarian security is 'agrarian resilience' coined by Soundarya (2017). Soundarya introduced this concept to explain about sustainable agricultural activities in rural areas in correlation to fragmented land tenure issues across generations. According to Soundarya, the capital invested in agriculture is very influential to agricultural resilience. Nevertheless, when it's invested into non-agricultural matters it will encourage a labour retreat from agricultural sector/activities.

Unlike Soundarya (2017) who coined the concept of 'agrarian resilience' that is associated with the resilience of agricultural activities in the rural areas, Oudenhoven et al (2011) proposed a 'resilience' concept linked to land use and ecosystem conservation in rural areas. Rapid changes in rural areas have caused compulsion in traditional patterns of management and utilisasion of agricultural lands which got significantly eliminated. Community and landscape resiliences in rural areas were strongly influenced by: traditional knowledge, cultural values, social institutions, and land use practices. Indicators which then were used to measure community and rural ecosystem resiliences include: knowledge sustenance and inheritance, demographics, cultural values, customary law, social institutions and autonomy, food sovereignty, complexity and intensity of interactions with ecosystems, and conservation of natural resources.

This study is different from those carried out by Soundarya (2017) and Oudenhoven et al (2011). The purpose was to analyse the dimensions of agrarian security of a particular community as well as the strategies to develop their agrarian security. According to Temudo and Schiefer (2003) pertaining 'agrarian society', agrarian security is crucial with regard to 'land' as the main source of welfare for agrarian villages and their communities. It is correlated to the ability to maintain their agrarian landscapes in the midst of swift dynamics in rural areas. The deagrarianization process, as mentioned by Lobban (2010), could reduce the ability of peasants' communities, leading to insecurity reflected in the capital accumulation among peasants.

\section{METHODS OF RESEARCH}

Indonesia as an agrarian country implied the symptoms of major deagrarianization, one of which can be seen through the decline of national Gross Domestic Product (GDP) from the agricultural business field. The largest national GDP contributor came from manufacturing industry business sector for the past 6 years (2012-2017) instead of the agricultural business field. Similar thing also happened in Java, one of the most densely 
populated islands in Indonesia as well as an island of main agricultural support, renowned for its rice paddy. This context became one of the arguments for choosing an agricultural community in Java, particularly Central Java to observe its dynamics in facing social changes in the rural areas.

Method used in this study was community case study method (Berg 2001). The community case study approach applied in this study was 'single case study' (Yin 2003). The procedure for community selection in this study was purposive sampling. Selected community was deliberately taken to be able to provide a 'layer in' depiction of the agrarian community in Central Java. The context of agrarian villages in Central Java that had been studied previously showed that agrarian villages were not only composed by communities with a single character as a community running a wetland cultivation (rice fields) business. Central Java has a long history of Sedulur Sikep or Samin community existence which was somewhat forgotten in the rural communities debate. They are more often perceived as 'the other community' who stay away and differentiate themselves from rural communities in general with their resistance movements and customs that seemed to be off-exposure to various changes occurring in the rural area. The dynamics put them as an escapism community that does not fit into modernisation narrative. Whereas, referring to Widodo (2000)'s affirmation, saminism is a phenomenon of the oldest peasant movement in Southeast Asia, making it fair to mention that they are an 'authentic' Javanese agricultural community or one essential part of the roots of Javanese agricultural civilization.

Sedulur Sikep community in Central Java has a long history as an authentic agricultural community with agricultural activities as their main source of livelihood. As Shiraisi (1990) and Peluso (2006) stated, the community's footprint from the beginning was to hold firmly onto agricultural sector instead of other livelihoods. Remote character itself is a result of socio-historical transformations that urged them to stay in areas which they deemed to be safe enough to maintain cultural autonomy as well as economic production activities. Indepth research was conducted at the Sedulur Sikep Community in Baturejo Village, Sukolilo District, Pati Regency, Central Java. This community is the latest generation of the glory of the Samin community who had entered Undakan (South Kudus) region since 1916 (Castle and Benda 1969).

For some people, this community is considered somewhat different from the rest. They labelled them as 'the inlanders' with reference to their typically traditional life. As Rosyid (2008) stated, the term 'Samin' was often derogated by public with a slang word 'nyamen', closely linked to deeds that violate habits. It tends to have a negative connotation, which later changed by its people whonamed themselves as 'Sedulur Sikep'.

Baturejo is a regional centre of Sedulur Sikep Community located in Sukolilo. There are 327 households or 1089 people, consisting of 467 males and 622 females. They accounted to $16.60 \%$ of Baturejo's total population, which amounted to 6557 individuals. As an agricultural village, Baturejo's peculiarity is marked by the rice mill (selepan) and the dried unhulled rice grain (paddy) on the yards which could be found easily in the village. Agricultural machineries such as tractors and rice threshers were also placed on the terrace or in front of the house. Rice field landscapes stretch north of the village settlement. There are 830 hectares of paddy fields consisting of 250 hectares of rice fields with technical irrigation, 530 fields with semi-technical irrigation, and 50 hectares of rainfed rice fields. In addition to paddy, corn and cassava are agricultural products that are widely planted by peasants.

The data source in this study consisted of primary data and secondary data. Primary data were obtained through observation and in-depth interviews. The informant selection technique performed by purposive sampling. Meanwhile, secondary data were obtained from statistical data issued by the Central Bureau of Statistics, the Department of Manpower and Transmigration, the Ministry of Agriculture's Data and Information System Centre, as well as population data and tax documents from village authority. The main informants in this study were peasants from the second and third generation in the community. There were 42 people consisting of: 29 members of Sedulur Sikep community, 8 people from non-Sedulur Sikep community, 2 village apparatus, and 3 officials from the local agricultural extension 
office. The emic perspective were applied in this research by conducting a close readingthrough ethnographic approach. Field study (live in) was conducted in the mid of 2017 and further re-visitation in the beginning of 2018, as well as some data renewal through long-distant interviews with the informants by the end of 2018 and the beginning of 2019.

\section{RESULTS AND DISCUSSION}

Deagrarianization is caused by growing assumption that agriculture is unable to provide adequate returns, increasing constraints in agricultural sector, as well as increasing opportunities in non-agricultural sectors (Rigg, 2001; Rehder, 2011; Rigg, 2006). The decline in the number of agricultural-oriented households in Pati Regency amounted to 76,659 households during 2003-2013, becoming an alarming situation that indicates backlash in agricultural sector. A relatively low income from farming activities made this sector that once popular during 1970s-1980s became less attractive.

At the macro-level, it can be seen that Peasant's Exchange Rate (PER) in Pati Regency for the last 3 years (2014-2016) showed no significant increase. The average PER were still at 101.61 point. It pinpointed a fact that the income from agricultural sector were slightly higher than their expenses. The surplus was only 1.61. This insignificant PER increase became a symbol of peasants' purchasing power, reflecting a slow growthoftheir welfare. It was further reinforced by empirical facts that peasants' income from agricultural sector were still lower compared to other economic sectors. The 2013 Agricultural Census specified that the wages of agricultural workers were nothinghigher than 1.2 million Rupiahs per month. This wage rate is far lower than the average labour income in general, reaching up tomore than 1.6 million Rupiahs per month. The unpopularity of agriculture is reflected upon peasants' pessimism in correlation to their agricultural activities.

A notion on agriculture as 'non-promising job' relatively came from the peasants themselves. The undertaken agricultural businesses were less innovative, inherited occupation which cannot be expected to suffice daily needs. Farming is deemed to be unable to provide success and welfare. This pessimistic attitude came from an assumption that farming does not bring any significant changes to their lives. It later encouraged the migration culture which is quite familiar to Sukolilo society. Data on the Foreign Workers Computerized System (SISKOTLN) from the National Board for Placement and Protection of Indonesian Overseas Workers (BNP2TKI) in 2018 pointed out that within the past 8 years (2011-2018), Indonesian migrant workers from Pati District who work abroad were up to 42,367 people or approximately $6.41 \%$ of the total 660,228 Indonesian migrant workers from 34 active sending districts in Central Java. In 2018, Pati Regency was still listed as the fifth largest contributor to Indonesian migrant workers in Central Java after Cilacap, Kendal, Brebes, and Banyumas with 3,700 migrant workers in total.

Amid the vortex of deagrarianization that occurs at the macro level, agricultural communities in the rural area turned out to show different situation. Sedulur Sikep Community as an example of community that upholds its traditionality, is not affected by deagrarianization as experienced by other agricultural communities around it. This community shows the reality of rural communities that still survive (exist) with its agriculture and not experiencing deagrarianization process. It becomes an anomaly to the surrounding rural communities which slowly but surely chose to withdraw from agriculture in order to open up to other opportunities, enabling welfare outcomes in more rational numbers. They maintain the importance of agriculture which for the surrounding communities have begun to be degraded by various secondary (non-agricultural) activities.

According to Bryceson (2002), characteristics of deagrarianization at community level can be seen through 4 main symptoms: 1) the decline in both food self-sufficiency ability and meeting basic needs; 2) livelihood dislocation, 3) agrarian inexistence and 4) spatial relocation. Research findings showed that there were not many deagrarianization traits found in Sedulur Sikep Community. Only 3 features out of 13 were found: declining capability for self-sufficiency and fulfilling basic needs, as well as limited spatial relocation as can be seen in Figure 1. The first two were also more related to changes in lifestyle and principles, not on 
the community incapabilities. It can be seen from their habits where they started to consume processed foods they bought from vegetable vendors to diversify their daily diet. Meanwhile, related to basic needs fulfillment, they have indeed explicitly refused free health insurance from the government and preferred to owe money to pay for medical expenses. It is associated to self-esteem and confidence not to live by asking help/assistance out of their community.

This agricultural community is very confident in their ability to defend agrarian landscapes and manage them throughout their life and their generations'. Agriculture was managed full time by utilising all available resources in the community. There were no tradition of 'farm labour imports' because they work on agricultural activities themselves along with their relatives and neighbours in managed lands.

Agrarian security can be seen through 4 major dimensions: agricultural land availability, access to land, land use orientation, and stability of the agricultural communities. It encompasses community's strategy to deal with risks and various scarcities occured within village scope and its agricultural work. Agrarian security correlates to community's ability to maintain balance of the agrarian landscapes amids multiple dynamics in the rural area. When a community possesses strong agrarian resilience, they have higher viability to survive deagrarianization. Strong agrarian security supports agrarian villages to exist and survive deagrarianization, whereas weak agrarian security causes agrarian villages to age or to turn into non-agrarian villages (plantation villages, industrial villages, mining villages) which can be seen in detail in Figure 1.

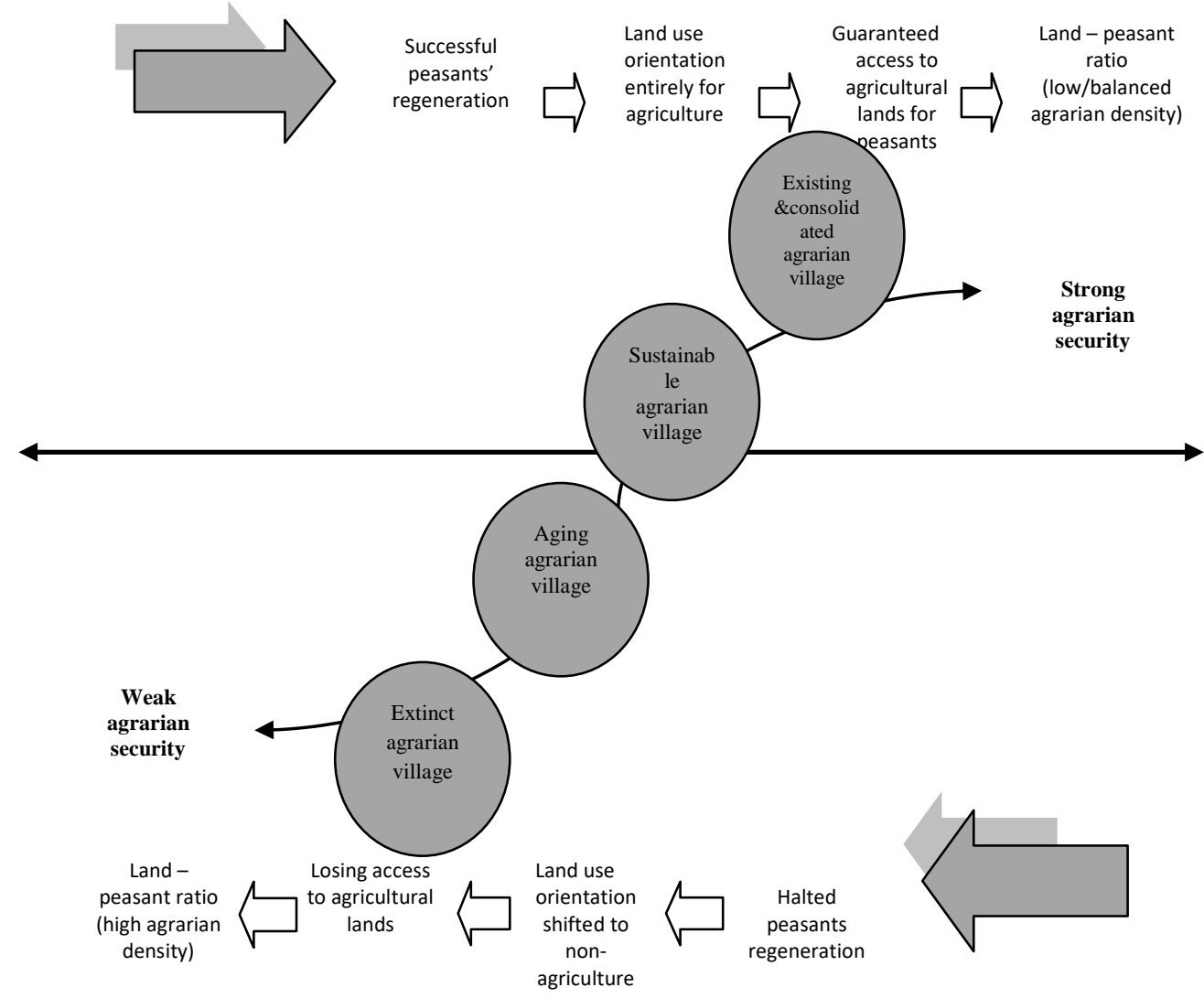

Figure 1 - Dimensions of agrarian security

Results pointed out that the community has a strong agrarian security. It can be seen through the attainment of three main dimensions of agrarian security: guaranteed access to agricultural land for peasants, full land use orientation for agriculture, and excellent peasant regeneration. Guaranteed access to agricultural land does not make younger generation lose their opportunity to own agricultural lands. Land use orientation that goes hand in hand with 
landscape productivity protects agrarian landscapes against deactivation (agricultural land abandonment) and changes in agricultural land use. Agricultural regeneration were successful because of community's unyielding principle to maintain agricultural activities and to become peasants. The agrarian security of Sedulur Sikep Community enables them to survive as a solid agrarian community with their agrarian lifestyle. Through accomplishing 3 main dimensions of agrarian security, this community can be a buffer group for existing and consolidated agrarian villages.

\section{CONCLUSION AND SUGGESTIONS}

In the midst of deagrarianization, Sedulur Sikep Community denotes its self-help values as an existing and consolidated agricultural community. Agrarian security enables them to survive as a solid agrarian community with its agrarian lifestyle until now. Land availability, access to land, land use orientation and community stability are amongst the agrarian dimensions that support the existence of this community. Strategy to develop agrarian security implemented by Sedulur Sikep Community carried out through expansion, population and exogamy, land tenure, reciprocity and collectivity, autonomy, scarcity, as well as agroecological and territorial strategies. Those agrarian security dimensions contribute to the ability of the community in preserving agrarian landscape, defending the community itself, and asserting its existence. Existing communities and agrarian landscapes indicated that deagrarianization will not simply afflict the existence of agricultural communities that possess strong agrarian security.

Agricultural communities with solid agrarian security are the key foundation for agrarian villages in the future. A strong agrarian security enables communities that support agrarian villages to continue preserving their agrarian way of life. With a strong agricultural security, they could sustain without having to transform into non-agricultural villages or to deal with the extinction of agrarian villages. When these agrarian villages turn into mining villages, industrial villages, plantation villages or livestock villages, the position of agrarian villages as the last stronghold of agrarian civilization will disappear.

\section{REFERENCES}

1. Berg, B.L. (2001). Qualitative research methods for social sciences. United States: Allyn and Bacon.

2. Bryceson, D. (1996). Deagrarianization and rural employment in Sub-Saharan Africa: A sectoral perspective. World Development. 24 (1), 97-111.

3. Bryceson, D. (2002). The scramble in Africa: Reorienting rural livelihoods. World Development. 30 (3), 725-739.

4. Bryceson, D. (2010). 'Sub-Saharan Africa's vanishing peasantries and the specter of global food crisis.' in Magdoff, F \& Tokar, B. (Ed.). Agriculture and Food in Crisis: Conflict, Resistance and Renewal. NYU Press: Monthly Review Press.

5. Castle, L., \& Benda, H.J. (1969). 'The Samin movement'. BKI deel 125.2e alvefering. Gravenhage: Martinus Nijhoff.

6. Connor, T., \& Mtwana, N. (2017). Vestige garden production and deagrarianization in three villages in the Eastern Cape, South Africa. South African Geographical Journal. 1, 1-22. doi:101080/03736245.2017.1301268.

7. Grivins, M., \& Tisenkopfs. (2018). Benefitting from the global protecting the local: The nested markets of wild product trade. Journal of Rural Studies. 61, 335-342. doi:10.1016/j.jrurstud.2018.01.005.

8. Gupta, D. (2005). Wither the Indian village: Culture and agriculture in rural India. Economic and Political Weekly. 40 (8), 751-758.

9. Halamska, M. (2011). The Polish rural area in the process of transformation 1989-2009. Polish Sociological Review. I (173), 33-54. 
10. Hisano, S., Akitsu, M., \& McGreevy, S.R. 2018. Revitalising rurality under the neoliberal transformation agriculture: Experiences of re-agrarianisation in Japan. Journal of Rural Studies. 61, 290-301.

11. McAllister, P. (1999). Agriculture and co-operative labour in Shixini, Transkei, South Africa. Working Paper 40. Grahamstown: Institute of Social and Economic Research and Leiden: African Studies Centre.

12. Misra, M. (2017). Is peasantry dead? neoliberal reforms, the state and agrarian change in Bangladesh. Journal of Agrarian Change. 17(3), 594-611. doi: 10.1111/joac.12172.

13. Murua, J.R., \& Astorkiza, I. (2013). Conflicts between agricultural policy and sustainable land use: The case of Northern Spain. PANOECONOMICUS. 3 Special Issue, 397-414. doi:10.2298/PAN1303397M.

14. Oudenhoven, F.J.W., Mijatovic., D., \& Eyzaguirre, P.B. (2011). Socio-ecological indicators of resilience in agrarian and natural landscapes. Management of Environment Quality: An International Journal. 22 (2), 154-173.

15. Peluso, L.P. (2006). Hutan Kaya, Rakyat Melarat, Penguasaan Sumber Daya dan Perlawanan di Jawa. Jakarta: Konphalindo.

16. Rehder, A., Dehu., C.B.M., Hasan, M.K., Waever, S.K., \& Gebremedhin, T.T. 2011. Intensification of agriculture and deagrarianization. Final Report. Thailand, Chiang Mai.

17. Rigg, J. (2001). Embracing the global in Thailand: Activism and pragmatism in an era of deagrarianization. World Development. 29(6), 945-960.

18. Rigg, J. (2006). Land, farming, livelihoods, and poverty: Rethinking the links in the rural South. World Development. 34 (1), 180-202. doi:10.1016/j.worlddev.2005. 07.015.

19. Rigg, J, Salamanca, A., \& Thomson, E. (2016). The puzzle of East and Southeast Asia's persistent smallholder. Journal of Rural Studies. 43,118-133.

20. Rosyid, M. 2008. Samin Kudus: Bersahaja di tengah asketisme lokal. Yogyakarta: Pustaka Pelajar.

21. Setiawan, U. (2013). "Desa sekedar tempat mudik". In Gunawan (Ed.). Rural talks: Ikhtiar memahami transformasi sosial-ekonomi masyarakat desa. Jakarta: IHCS.

22. Shiraisi T. 1990. 'Dangirs' testimony: Saminism reconsidered. Indonesia. 50, 95-120.

23. Soetarto, E., \& Agusta, I. (2012). "Arah baru penurunan ketahanan pangan: Deruralization, depeasantization, deagrarianization". In A, Fariyanti. (Ed.). Pangan rakyat: Soal hidup atau mati 60 tahun kemudian. Jakarta: Departemen Agribisnis. Bogor: FEBIPB and PERHEPI.

24. Soundarya, I. (2017). Dynamics of rural transformation in Karnataka a view from three village. (Unpublished Doctoral Thesis). Manipal University, India.

25. Tanaka, K. (2014). Reimagining the future of agriculture: building knowledge for sustainability and resilience. Journal of Rural Social Sciences. 29 (1), 1-16.

26. Temudo, M.P., \& Schiefer, U. (2003). Disintegration and resilience of agrarian Societies in Africa-the importance of social and genetic resources: a case study on the reception of urban war refugees in the South of Guinea-Bissau. Current Sociology. 51 (3), 393-416.

27. Tendall, D.M., Joering, J., Kopainsky, B., Edwards, P., Shreck, A., Le Q,B., Kruetli, P., Grant, M., \& Six, J. (2015). Food resilience: defining the concept. Global Food Security. 6, 17-23.

28. Van Dijk, M., \& Meijerink, G.W. (2014). A review of global food security scenario and assessment studies: result, gaps and research priorities. Global Food Security. 3: $227-$ 238.

29. West, J., \& Haug, R. (2017). The vulnerability and resilience of smallholder-inclusive agricultural investments in Tanzania. Journal of Eastern African Studies. 11 (4), 670-691.

30. White, B., Borras, S., Hall, R., Scoones, I., \& Wolford, W. (2012). The new enclosures: critical perspectives on corporate land deals. The Journal of Peasant Studies. 39 (3-4), 619-647.

31. Widodo, A. (2000). 'Untuk hidup tradisi harus mati'. In Basis, September-October edition. Yogyakarta: Yayasan BP Basis.

32. Yin, R.K. (2003). Case study research design and methods (3rd ed.). London: Sage Publications. 